\title{
Introduction: Difference, Culture, Society, Class
}

Arnar Árnason

Almost thirty years ago, Margaret Thatcher infamously declared that there is no such thing as society. She was followed, a few years later, by anthropologists eager to dismantle the concept of society, albeit for really quite different reasons. Maybe this time the anthropologists got there ahead of the politicians. Some twenty-five years after anthropologists seriously started to question their particular multiculturalism, politicians of quite some influence have declared it defunct.

The ideas of culture and society both speak of difference. It is to state the obvious to say that difference is what anthropologists deal in and with. It is to state the painfully obvious to say that difference and how we think about it is of monumental importance. Viveiros de Castro has of course reminded us of what has tended to be anthropology's particular version of difference: nature, biology, human nature unites but on top of that we find cultural differences. This is not terribly far from the multiculturalism that politicians speak of; their policy that allows for differences in traditions, as they might have it, but differences subsumed within universal values. The implication inherent in the anthropological idea is of course that differences are, even if deeply ingrained, learnt, rather than something people are born with. This is an obvious point but a point that is sometimes lost. And if differences are learnt, then they can also be unlearnt. I stress this because multiculturalism has both anthropologically and politically received some bad press of late. There are good reasons for this. Yet surely it remains a fact, and a fact that our ideas need to cope with, that we learn most of the things that determine the most important aspects of our beings. And what we learn depends greatly on where we learn them and from whom. Surely the anthropological variety of multiculturalism is not entirely spent. But we should also not forget the value of the political version of multiculturalism. As Gillian Evans stressed in a talk in the Department of Anthropology in Aberdeen recently, multiculturalism in the U.K. has been very successful in the fight against racism. I would only add to this the conviction that Franz Boas's arguments for culture and against race remain the most important contribution that anthropology has made to public debates.

Still, multiculturalism has its problems and we should not ignore these. In the talk mentioned above, Gillian Evans noted how the discourse of multiculturalism has robbed those designated as ethnic minority of understanding and of presenting their situation in terms of social class. They are forced to speak of their difference in terms of culture when oftentimes what marks their situation is poverty and lack of job opportunities. This understanding is backed up with a significant amount of research that suggests that differences in health between ethnic groups are less clear when class differences that exacerbate minority ethnic status are taken into account. ${ }^{1}$ At the same time, Evans added, this leaves white working-class people without an adequate language to voice their concerns, an issue 
raised in Katherine Smith's paper in this issue. There is no readily available language of white working-class culture, and attempts to articulate it feel inauthentic. Here multiculturalism may of course work as a tool to divide along ethnic lines those who otherwise have a more fundamental class status and class interests in common. ${ }^{2}$

If these are the political problems associated with multiculturalism then perhaps the anthropological challenge should be voiced too. For the idea of culture either tends to imply a hierarchy of differences or the flattening out of all differences so that all differences seem equally important. Further, the traditional anthropological picture, the one that Viveiros de Castro has sought to dismantle, always suggests a more fundamental importance and similarity underneath the differences. This understanding has positive political consequences in many cases. But it can have questionable consequences too, of course, as evidenced in Laura Jeffery's and James Oliver's contributions.

Maybe, then, I should use this opportunity to stress the importance of society as an idea to talk not about solidarity and functional coherence, but difference. In particular I should perhaps draw yet again on Gillian Evans to emphasise the enduring importance of class when it comes to the ethnographic reality, as I was taught to call it, of Britain. Ignoring that reality has, furthermore, significant political consequences. Political rhetoric in this country has for some time worked against the idea of class as destiny, as fate, as something into which and with which people are born and from which they cannot escape. Political rhetoric has, in other words, worked against the essentialism that sometimes seems - at least to those of us that come to this system from the outside - to be attached to people's class identifications in Britain. But political rhetoric has only worked against the notion of class to emphasise individual social mobility. With that political rhetoric has undermined the language of class as collective identity and as the basis for people's collective, political struggle. Asserting the continuing ethnographic importance of class is a political task; it is anthropology in action.

The articles assembled here were first presented as papers at a workshop in Aberdeen in 2008, supported by the ASA's Anthropology of Britain Network. The theme of our meeting was 'Learning and unlearning to be British'. The context was ongoing public debates about immigration, integration and terrorism; a political obsession, it seemed, to articulate the essence of Britishness and British values; but also further developments in political devolution and hints towards independence, as in the case of Scotland, a point taken up by Alexander Smith in his contribution here. It became clear during the session and the writing that followed that the theme of difference is indeed what animated most of the papers and the discussions. The articles that follow speak for themselves.

It only remains for me to stress again the importance of the theme. And to acknowledge and express my gratitude for the support of Catherine Degnen and Katherine Tyler of the ASA Network, of the ASA itself, of my colleagues in Aberdeen, Jo Vergunst and Andrew Whitehouse, and of the editor of Anthropology in Action.

\section{Arnar Árnason \\ Department of Anthropology \\ University of Aberdeen}

\section{Notes}

1. I am indebted to Christine McCourt for this point

2. I owe Christine McCourt this point too. 